\title{
A Year of Living Dangerously: Challenges and Recommendations for Safely Performing Ophthalmic Surgery During the COVID-19 Pandemic, from Start to Finish
}

This article was published in the following Dove Press journal:

Clinical Ophthalmology

\author{
Juan Pablo Salica $\mathbb{1}^{1-3}$ \\ Constanza Potilinski $\mathbb{D}^{3}$ \\ Marcia Querci ${ }^{4}$ \\ Ignacio Navarro ${ }^{3}$ \\ Juan Sebastián Rivero' \\ Pablo Daponte' \\ Roberto Pineda ${ }^{5}$ \\ Juan E Gallo $\mathbb{D}^{2,3}$ \\ 'Committee for Prevention of Ocular \\ Infections, Argentinean Ophthalmology \\ Council, Buenos Aires, Argentina; \\ ${ }^{2}$ Department of Ophthalmology, Hospital \\ Universitario Austral, Pilar, Buenos Aires, \\ Argentina; ${ }^{3}$ Nanomedicine \& Vision Lab, \\ Instituto de Investigaciones en Medicina \\ Traslacional, Universidad Austral, \\ CONICET, Pilar, Buenos Aires, \\ Argentina; ${ }^{4}$ Division of Infectious \\ Diseases, Centro de Educación Médica \\ e Investigaciones Clínicas Norberto \\ Quirno (CEMIC), Buenos Aires, \\ Argentina; ${ }^{5}$ Massachusetts Eye and Ear \\ Infirmary, Harvard Medical School, \\ Boston, MA, USA
}

\begin{abstract}
The COVID-19 pandemic has forced all nations to take an active role in infection control incorporating recommendations and measures to control viral dissemination. The epidemiological impact is very diverse and dynamic, even within the same region. Scientific knowledge regarding SARS-CoV-2 continues to improve every day with protocols needing to be updated and adjusted on a regular basis. Ophthalmology is a medical specialty identified to be at high risk for several reasons: it has very close doctor-patient contact, the virus has been detected in tears, and the ocular surface serves as a gateway to developing the infection. We have reviewed the current information on SARS-CoV-2 in the ophthalmologic field and provide up-to-date recommendations to help create protocols that can adapt to the dynamic situation of ophthalmologic institutions, patient cases, economic situations and access to diagnostic tests. This paper outlines the main recommendations regarding the initial consultation and outpatient clinics, measures to apply in the operating room (OR), and suggestions for post-surgical controls. Triage, according to the patient's conditions and eye pathology, reduction of the time the patient is at the institution, social distancing, correct use of personal protective equipment (PPE), barrier methods, hygiene, as well as other recommendations mentioned in this document, will allow physicians to take care of the visual health of the patients while reducing the impact of the COVID-19 pandemic.
\end{abstract}

Keywords: SARS-CoV-2, COVID-19, ophthalmology, eye, surgery

\section{Introduction}

The world is about to reach 1 year dealing with the COVID-19 pandemic, offering a mixed picture, with countries that are dealing with the second wave of this disease, some are just getting out of the first wave, while a minor sector is still waiting for the hit after travelling restrictions quit.

The future in the medium term is promising with hundreds of vaccines under research, with a few already in phase 3 accounting for over $90 \%$ of efficacy. In the short term, this pandemic is still forcing all nations to take an active role in infection control incorporating recommendations and measures to limit economic, social and health consequences related to the virus.

Some patients with ophthalmic pathologies (urgent and chronic) still postpone consultations, occasionally due to risk factors for COVID-19, but most frequently because of lack of information and fear of being exposed to the virus.
Correspondence: Juan Pablo Salica Consejo Argentino de Oftalmología, Tte. Gral. Juan D. Perón I479, PB. Zip Code CI037ACA, Ciudad de Buenos Aires, Argentina

Email jp.salica@gmail.com 
Ophthalmologists, on the other side, evidence the consequences of the absence of appropriate follow-ups and consultations as well as the updated descriptions of the impact of SARS-CoV-2 and the new lifestyle on visual health.

In this review, we examine the latest recommendations and main challenges in the ophthalmic field to reduce COVID-19's impact learnt during the first year of the pandemic, to be applied at the present time or to future waves. Recommendations might be useful for other viral pandemics in the future.

\section{Methods}

A comprehensive review of the literature was carried out through PubMed beginning in April 2020. This search was conducted on regular basis due to a large number of articles being published. The amount of new information published in the short window shows the importance of this topic to health professionals, health systems, and government decision-makers.

The following PubMed terms in diverse combinations were used to search for related articles in this review: SARS-CoV-2, COVID-19, transmission, risk factors, eye, ophthalmology, ophthalmologist, surgery, operating room, conjunctivitis, personal protective equipment (PPE). A subsequent search was conducted when the terms were relevant. Publications cited in the articles selected by the search were also retrieved. Furthermore, special links related to COVID-19 on the National Center for Biotechnology Information (NCBI) site were checked, as well as public health information from the Centers for Disease Control and Prevention (CDC) and the National Institute of Health (NIH). Also, the World Health Organization (WHO) site was consulted. Previous to the publication's date there were no restrictions applied.

\section{COVID-I 9 Pandemic}

Coronavirus is a family of enveloped positive-sense, single-stranded RNA viruses associated with a range of digestive and respiratory diseases: common cold, bronchitis, bronchiolitis and mild to severe pneumonia. Two members of this family have caused epidemic disease in the past: Middle East Respiratory Syndrome-related Coronavirus (MERS-CoV) and Severe Acute Respiratory Syndrome Coronavirus (SARS-CoV). ${ }^{1}$

SARS-CoV-2 (Severe Acute Respiratory Syndrome Coronavirus 2) is the name that the World Health Organization (WHO) assigned to a novel coronavirus responsible for the outbreak of COVID-19 (Coronavirus Disease 2019) in Wuhan city, province of Hubei, China on 31 December 2019. ${ }^{1}$ One month later, the Emergency Committee of the WHO declared the disease outbreak a Public Health Emergency of International Concern. ${ }^{2}$

COVID-19 has a global impact due to its rapid viral spread aided by an international travel sector, which has led to even more rapid dissemination of the disease and to the health system's collapse, even of those that were thought to be robust. ${ }^{3}$ Up to now, counting with treatments without demonstrated efficacy and some promising vaccines currently in phase 3 of clinical trials to limit the COVID-19 pandemic, a preventative strategy focused on proper epidemiologic measures and maximizing infection control are warranted. ${ }^{4}$

In order to develop a program to control and prevent the spread of the disease in healthcare facilities, it is important to understand the various ways in which pathogens are transmitted: through direct contact, fomites, oral (ingestion), vectorborne, and droplets (respiratory droplets: $>5$ to $10 \mathrm{um}$, and airborne or droplets nuclei: $<5 \mathrm{um}) .{ }^{5}$ Airborne droplets may remain in the air for long periods of time and be transmitted to others over distances greater than one meter. ${ }^{6}$

The main vehicle for the transmission of SARS-CoV-2 is respiratory droplets and direct contact. ${ }^{7}$ The mechanism of SARS-CoV-2 is presumed to infect the human cells by spike glycoprotein binding to its cellular receptor, angiotensinconverting enzyme 2 (ACE2). Thus, the main virus entry occurs through nose, mouth and eyes cells that have the ACE2. ${ }^{8-10}$

Even though there is evidence of viral shedding in the excreta of COVID-19 patients, currently, there are no reports of faecal-oral transmission. ${ }^{11}$ Similarly, there is no evidence that SARS-CoV-2 undergoes intrauterine or transplacental transmission, but some recent case reports have suggested this might be possible. ${ }^{12}$

Cross-sectional and experimental studies indicate that the virus can remain viable and infectious for hours or even days depending on the material where the inoculum is placed. ${ }^{13-15}$

In the context of COVID-19, to protect patients and health care providers, infection control has to focus on direct contact, and the airborne droplet transmission in ophthalmology may be possible in specific circumstances and settings in which aerosolizing procedures are performed. ${ }^{16}$

\section{SARS-CoV-2 and Eye}

The human ocular surface epithelium provides an additional entry portal for SARS-CoV-2. ${ }^{17,18}$ In fact, there are 
some reports that indicate that the eyes were the suspected gateway for the virus. ${ }^{10,19}$

Several studies have documented the presence of SARS-CoV-2 genetic material on the ocular surface which was detected in conjunctival swabs and tears after performing a reverse-transcription polymerase chain reaction (RT-PCR) assay for the detection of viral RNA in COVID-19 positive patients. A meta-analysis showed that this situation is still controversial and not very frequent, with estimated positive swabs in $1.95 \%$ of the cases $(95 \%$ C.I. 0.74 to 4.11$){ }^{20-22}$ At the moment of analysing the reason for this low percentage, one has to consider the effect of broad-spectrum antivirals in topical ophthalmic medications, a fact not reported in most publications. ${ }^{23}$

Viral RNA of SARS-CoV-2 was also detected in the retina of COVID-19 patients. ${ }^{24}$ Also, in a cross-sectional study, retinal and vasculature alterations were detected correlating with COVID-19 disease severity in 54 patients. ${ }^{25}$ Recent evidence demonstrated the presence of SARS-CoV-2 in the vitreous and cornea, highlighting the criticality of donor screening guidelines and the plausibility of human eye tissue or eye fluids to be a source of infection. ${ }^{24,26}$

The ocular manifestations of COVID-19 include mainly signs and symptoms compatible with follicular conjunctivitis. The incidence of conjunctivitis is estimated around $1 \%$ to $3 \%$ and is related in a meta-analysis to more severe forms of COVID-19. ${ }^{20,27}$ Few articles have reported keratoconjunctivitis as the first symptom of COVID-19. ${ }^{28,29}$

Findings on the retina of COVID-19 positive patients include cotton wool spots and microhemorrhage at fundus examination. OCT findings were hyperreflective lesions at the level of ganglion cell and inner plexiform layers more prominently at the papillomacular bundle in both eyes. Results of OCT-angiography and ganglion cells complex analysis appeared normal. ${ }^{30}$

Some authors reported an increase in dry eye syndrome symptoms along with this pandemic. This might be due to a double mechanism: the mass use of face mask (incorrect fitting of the mask could disperse air around the eyes) and the increase in exposure to computer screens and cell phones (prolonged blinking intervals). ${ }^{31}$ Another finding, suspected as a possible COVID-19 repercussion, is the Sanitizer aerosol-driven ocular surface disease (SADOSD). ${ }^{32}$

\section{SARS-CoV-2 and Eye Care}

At the beginning of the COVID-19 pandemic, the initial recommendation the population heard was: "stay at home". This was strongly remarked for elderly people and especially with comorbidities. Scientific associations communicate to postpone non-essential outpatient visits and elective surgical procedures. Soon expert panels defined what should be considered urgent to take care of, and once protocols were applied to control viral dissemination, eye care institutions reopened making a big effort to work in the new normal.

There was an evident delay in visits to the eye doctor, which still persists, turning acute and chronic pathologies to be misattended. This is frequent in patients with risk factors, due to fear and lack of correct information. At the top rank of eye, pathologies are diabetic retinopathy, glaucoma and maculopathies. As we all know, they are sightthreatening diseases that may have a devastating impact. Patients and ophthalmologists are witnessing this trend that needs to revert; otherwise, this process could lead to a dramatic increase in disability, with an increase in social and government costs. ${ }^{33,34}$

\section{Outpatient Clinic and General Presurgical Consideration Consideration in the Outpatient Clinic}

Measures to lower the risk of exposure to SARS-CoV-2 should be bidirectional, they aim to take care of the patients and the staff. ${ }^{35}$

To plan a first contact with the patient in a remote way, promoting telephone consultation and/or telemedicine care, might be the most logical way to start. It is favourable to 1) give instructions about the visit, ${ }^{36}$ 2) make a triage, 3) advance with interrogation, and to reduce the time of the visit.

A triage aims to detect possible cases of COVID-19 and refer them to receive specialized attention, to differ the consultation whenever possible, to solve the patient's problem via telemedicine care, and to define the circuit the patient should go for the personal consultation $^{37}$ (Figure 1).

It may be useful to give informed consent to the patient before the appointment. It should be adapted to local law and it should basically inform the patient about the risks during the pandemic, while at the same time, it may serve as a written declaration of symptoms compatible with COVID-19 or of contact with confirmed cases. ${ }^{38}$

Appointments should be organized in such a way that the patients do not overlap in common areas. The patient should be indicated to come alone or explained that their 


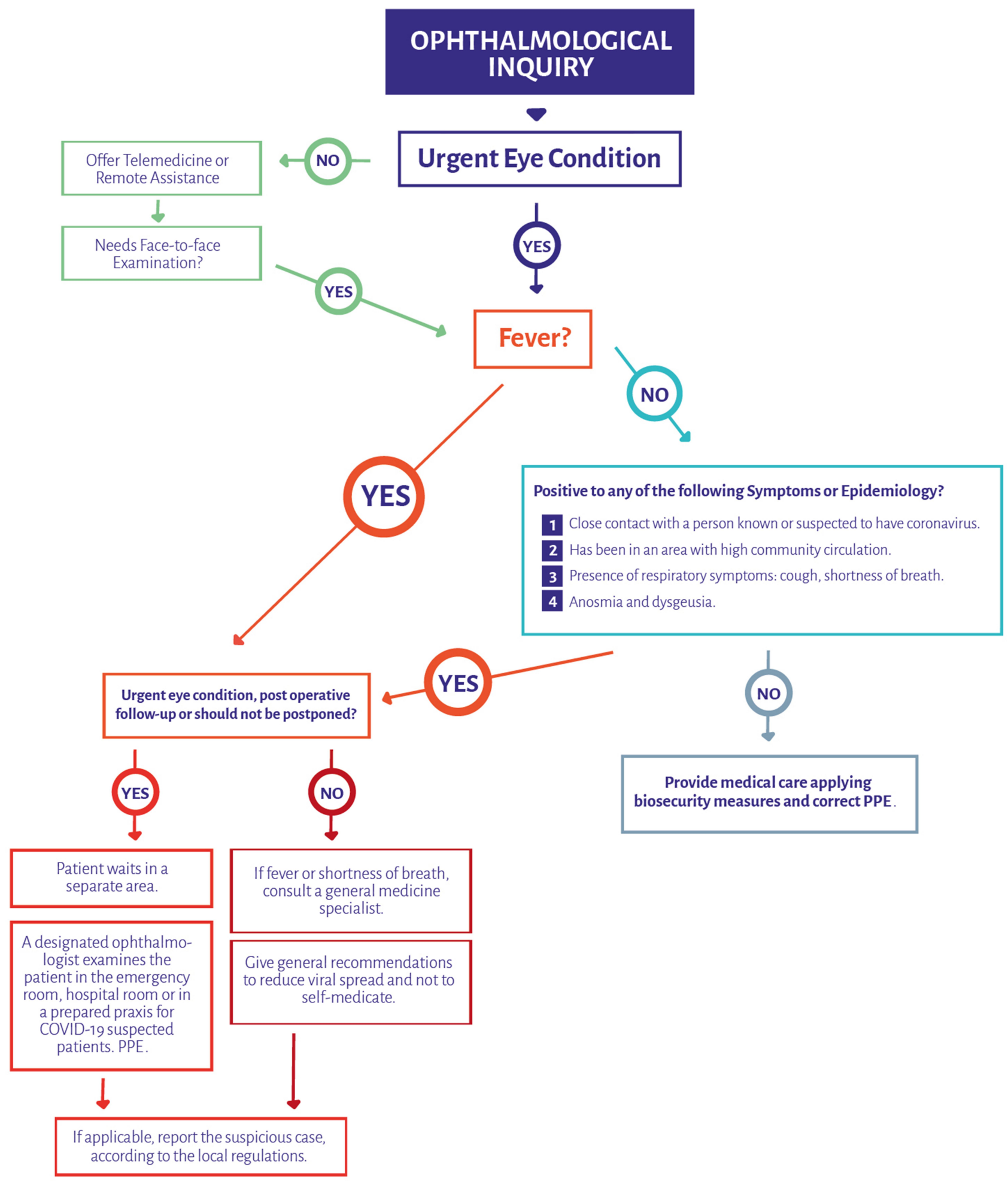

Figure I Suggested flow-chart to deliver ophthalmologic assistance during COVID-19 pandemic.

companion should wait outside the facility if possible. It is also good to remind them to use a mask and eye protection. ${ }^{39-41}$ Once the patient arrives, triage should be repeated. Provide alcohol-based hand sanitizer. ${ }^{42}$
Once the patient enters the examination room, the ophthalmologist should wear PPE according to the exposure planned. It is not common that ophthalmologists perform aerosol-generating procedures at the praxis. The risk 
comes mainly because of the very close working distance between doctor and patient and when getting in touch with the mucosae, ocular secretions, and tears. For a safe working environment, it is important to train the healthcare team in the proper use of PPE. ${ }^{43,44}$

\section{PPE Considerations in Ophthalmology Respiratory Protection}

There is consensus that the use of N95 respirators and face masks is indicated when facing patients who are COVID19 positive or suspected to be infected during the aerosolgenerating procedure. ${ }^{17,38,45-48}$

Nevertheless, during a simulated clinical activity, airborne aerosol generation was evidenced during speech and sneezing. N95 respirators mitigated airborne aerosol transmission while standard surgical masks did not. ${ }^{49}$ Given this evidence, N95 respirators would provide physicians and healthcare workers with major protection.

When the supply of N95 respirators is short, they should be kept for high-risk use and aerosol-generating procedures only. ${ }^{22}$ Evaluate contingency measures for reprocessing N95. ${ }^{50-52}$ The National Institute for Occupational Safety and Health (NIOSH) published a recommended guidance for extended use and limited reuse of N95 filtering facepiece respirators in healthcare settings, which emphasizes there is no determined limited time of use when a shortage of supplies.

\section{Eye Protection}

When close contact is required, eye protection equipment should be used as part of a full PPE. ${ }^{39}$ Goggles should be worn for aerosolizing procedures, while glasses with an enveloping design may be easier to wear at the consultation.

\section{Hand Protection}

One of the most important prevention methods is hand hygiene. ${ }^{53}$ Alcohol-based formulations proposed by the World Health Organization (WHO) are proved to be highly efficient. ${ }^{42}$ The use of gloves is important when having direct contact with the patient. Gloves are subject to single-use. Ensure their removal does not cause additional contamination of hands. ${ }^{17}$

\section{Body Protection}

The physicians should protect their personal clothes with a white coat, disposable fluid repellent coveralls, or longsleeved disposable fluid repellent gowns. These last two options will be required for aerosol-generating procedures.
The clothing can be worn for a single session. This means it should be changed every time that a health worker leaves a specific clinical care setting or exposure environment. $^{17}$

\section{Eye Examination Considerations to Reduce Viral Transmission}

- Breath shields or slit lamp barriers are a must at this moment. ${ }^{37}$

- When testing for visual acuity, a phoropter is easier to sanitize.

- A hypoallergenic tape can be placed on the nose bridge of the surgical mask or cloth mask of the patient, to avoid blurring of the glasses with breathing vapour. This may be useful as well for other proceedings.

- Binocular indirect ophthalmoscope delivery system is preferred for fundus examination at the slit lamp.

- Determine intraocular pressure only when necessary in this transition time of the pandemic. Disposable tonometry devices are preferred. Avoid non-contact "air-puff" tonometry, since it generates aerosol. ${ }^{54}$ Perkins tonometer use is also discouraged since it requires extremely close working distance. The use of alcohol $70 \%$ should be effective at disinfecting tonometer tips from SARS-CoV-2, always remembering it would not be enough to inactivate adenovirus. In this last case, sodium hypochlorite dilution would be effective.

- Keep communication between patients and physician as minimum as possible during the visit. Avoid talking during a close examination. ${ }^{55}$

- Strive to perform all the studies needed during the same visit.

- When multidose eye drops are required, evaluate fractioning for daily disposal. Try not to touch the ocular surface nor the eyelashes with the tip of the eye drop bottle at the moment of instilling it as it should be. ${ }^{56}$

- Disinfect your hands after having any contact with the patient.

- Take notice of the instruments and medications' placement in the consulting room, avoid their contamination and any source of transmission.

- Try to reduce ophthalmic diagnostic testing mainly when they will not change treatment criteria.

- Companies are developing and already offering ophthalmic equipment with a remote command to preserve social distancing. 
- Manufacturers are providing guidance on their websites on the disinfection process of specific equipment. $^{57}$

\section{General Considerations for Ophthalmologic Institutions}

Ophthalmologist and ophthalmic administrators should introduce structural and organizational changes to their institutions (Table 1).

\section{Defining Cases, Triage and Screening Process Defining Criteria for Appropriate Surgical} Cases

The crucial step is to define the epidemiological situation the ophthalmic institution is immersed in, and its real capacity to handle urgent or elective surgeries in this pandemic.

In order to create a formal frame to list urgencies that should be attended, the Argentinean Council of Ophthalmology created a consensus by an expert panel, conformed by representatives of each ophthalmic subspecialties societies of Argentina, the Committee for Prevention of Ocular Infections and the Chairs of the Ophthalmology Department of all the Universities of Argentina. ${ }^{61}$ In its turn, different societies worldwide gave similar suggestions. ${ }^{62}$ It is important to highlight that the medical criteria to decide what case should be operated on will always be fundamental.

Before performing eye surgery for a given case, the ophthalmologist has to consider and evaluate risks and benefits very thoroughly. As stated by the Centers for Disease Control and Prevention, USA (CDC), people at a higher risk are older adults (with 65 years old or above) and people with underlying medical conditions (such as chronic lung disease or moderate to severe asthma, a serious heart condition, severe obesity, diabetes, chronic kidney disease undergoing dialysis, liver disease and those immunocompromised). Every mentioned situation could represent serious disadvantages when performing surgery. ${ }^{63,64}$

A retrospective study on patients that developed COVID-19 pneumonia shortly after general surgery were older, more likely to have underlying comorbidities and underwent more difficult surgeries. ${ }^{64}$ This impact was not studied on ophthalmic operated patients, ocular surgery should not have the same negative repercussions on COVID-19 evolution, since it does not have an important
Table I General Recommendations for Institutions and Health Workforce

\begin{tabular}{|l|l|}
\hline Concerning & $\begin{array}{l}\text { Recommendations } \\
\text { Institution }\end{array}$ \\
- It is wise to have two different clear circuits. One \\
for patients who have tested negative for COVID- \\
I9 and one for patients with symptoms or sus- \\
pected epidemiological background positive to \\
COVID-19. \\
Cose a signalling system to indicate circulation, \\
where people should stand, where they should \\
sit, to remind them to keep social distancing. \\
- ${ }^{5,59}$ \\
Make sure to install desks and countertop barriers \\
for employee protection. \\
- As a way to reduce the use of PPE and avoid viral \\
transmission, physical barriers, such as acrylic or \\
glass windows, could be installed.
\end{tabular}

hemodynamic impact, the area of compromised tissue is small and anaesthesia is usually done locally.

In this pandemic context, surgeries have been curtailed to preserve resources to face special medical needs raised by COVID-19. Elective surgery could be understood as optional in this scenario. Nevertheless, if surgery was consent between the patient and the physician, except limited cases, has implicit an important rationale backingup the indication. If the pandemic prolongs, the elective surgeries need to come to the agenda (Table 2). 
Table 2 Facts to Consider in the Decision-Making Process Regarding the Necessity of the Elective Eye Surgery During COVID-19 Pandemic

\begin{tabular}{|l|l|}
\hline $\begin{array}{l}\text { Concerning } \\
\text { Area }\end{array}$ & Facts to Consider \\
\hline Institution & $\begin{array}{l}\text { Resource limitations (PPE, health workforce, OR } \\
\text { necessity for other urgent procedures) } \\
\text { - COVID-19 transmission risk } \\
\text { - Ophthalmic Institution Only/General Hospital } \\
\text { - OR facility and installation }\end{array}$ \\
\hline Patients & $\begin{array}{l}\text { Individual patient risks } \\
\text { - General anaesthesia necessity } \\
\text { - Case prone to complications } \\
\text { - Ocular disease }\end{array}$ \\
\hline Time & $\begin{array}{l}\text { Duration of surgery } \\
\text { - Disadvantages of postponing operation in the sur- } \\
\text { gical outcome or disease process. }\end{array}$ \\
\hline Surgery & $\begin{array}{l}\text { Postoperative complications and readmissions } \\
\text { - Assess the effectiveness of nonoperative treat- } \\
\text { ment options. }\end{array}$ \\
\hline
\end{tabular}

A group of the University of Chicago Medicine and Biological Sciences proposed a scoring system to ethically and efficiently manage resource scarcity and provider risk during the COVID-19 pandemic called Medically Necessary, Time-Sensitive Procedures (MeNTS). They considered 21 factors divided into three main areas: procedure factors, disease factors and patient factors. This system offers an objective way to ponder the indication of surgery. It helps to consider the major variables that may have an impact on the risk of the surgery. ${ }^{65}$

The Spanish Association of Surgeons published a dynamic scale of five possible scenarios/alerts that take into account the percentage of beds occupied by COVID-19 patients in ICU, the compromise of resources, and the surgical procedures that should be performed. ${ }^{66}$ Taking this scale into account and adapting these criteria to ophthalmology, we could plan our surgical indications in five different scenarios given mainly by the curve of the infection and its direct relationship to the percentage of ICU occupancy (Table 3).

Along stages 1 to 4 , ophthalmologists should always consider proceeding with promptness to operate in urgent cases. Close to scenario 5, it is interesting to have in mind that it may be important to increase the critical care capacity and, since elective surgeries are postponed, ORs and postanesthesia care units (PACUs) could be converted into ICUs. ${ }^{67}$

\section{Preoperative Screening Process to Rule Out COVID-19}

The main objective of making a COVID-19 screening is to avoid transmission of the illness along the surgical process, to keep a circuit that is free of COVID-19 and to decrease risk in presymptomatic patients who could be operated while infected with SARS-CoV-2.

Since the beginning of the outbreak of the virus in Argentina, as well as in many other countries, the health system has had significant limitations of their diagnostic testing capabilities. Moreover, such limitations became much clearer when the restrictive criteria for testing control were removed by the CDC. ${ }^{68}$ Until today physicians are recommended to use their judgment for screening patients and setting up biosecurity protocols. For this matter, we have included a variety of screening methods reported in multiple publications stating their results and limitations.

The preoperative screening will vary depending on each facility's capacities, its epidemiological context, the type of patient, and the availability of diagnostic tests.

\section{Epidemiologic and Symptomatic Triage}

This evaluation aims to identify patients who are highly suspected of SARS-CoV-2 infection, regardless of any diagnostic test results (Table 4). ${ }^{69,70}$

The evaluation is suggested to be made using telemedicine within $72 \mathrm{~h}$ before the surgery. It should be repeated in person on the day of the surgery.

Another approach recommends to carry it out 14 days before the proceeding, recommending the patient to avoid exposure to possible sources of contamination in their community. ${ }^{71,72}$ Triage results should be included in the patient's medical history.

\section{Diagnostic Tests for Detection of SARS-CoV-2 Nasopharyngeal RT-PCR}

Real-time reverse-transcriptase polymerase chain reactionbased assays performed in a laboratory are the reference standard for COVID-19 diagnostics. There are protocols that include this exam as a routine previous to any ophthalmic surgical procedure.

It is the most reliable test that confirms active infection because it has a high specificity to detect the virus (low rate of false positive).

Nevertheless, its sensitivity is estimated to be $70 \%$. This means a high rate of false negative. ${ }^{73}$ This estimate will be modified mainly by the chances of infection of the patient's community (pretest probability) and the quality 
Table 3 Comparative Chart: Different Possible Scenarios According to the Percentage of Intensive Care Unit Occupancy

\begin{tabular}{|l|l|l|l|l|l|}
\hline $\begin{array}{l}\text { Percentage of ICU } \\
\text { Occupied by COVID-19 } \\
\text { Patients }\end{array}$ & $<5 \%$ & $\mathbf{6}$ to $\mathbf{2 5 \%}$ & $\mathbf{2 6}$ to $\mathbf{5 0 \%}$ & $\mathbf{5 1}$ to $\mathbf{7 5 \%}$ & $>\mathbf{7 6 \%}$ \\
\hline Resources & Not compromised & Not compromised & Generally compromised & Compromised & Very Compromised \\
\hline Surgical Activity & $\begin{array}{l}\text { Complete, with } \\
\text { caution }\end{array}$ & Reduced & Limited to urgencies & $\begin{array}{l}\text { Limited to } \\
\text { urgencies }\end{array}$ & Emergencies \\
\hline Main indications & $\begin{array}{l}\text { Pathologies that } \\
\text { compromise the } \\
\text { quality of life }\end{array}$ & $\begin{array}{l}\text { Limited to sight- } \\
\text { threatening } \\
\text { pathologies }\end{array}$ & $\begin{array}{l}\text { Limited to sight- } \\
\text { threatening pathologies }\end{array}$ & $\begin{array}{l}\text { Limited to sight- } \\
\text { threatening } \\
\text { pathologies }\end{array}$ & $\begin{array}{l}\text { Limited to life- } \\
\text { threatening } \\
\text { pathologies }\end{array}$ \\
\hline
\end{tabular}

Table 4 Facts to Inquire in the Triage Process During COVID-19 Pandemic

\begin{tabular}{|c|c|c|c|c|c|}
\hline \multirow[t]{2}{*}{ Triage } & Scenario I & Scenario 2 & Scenario 3 & Scenario 4 & Scenario 5 \\
\hline & \multicolumn{5}{|c|}{ Assessed Variables } \\
\hline Clinical & \multicolumn{5}{|c|}{$\begin{array}{l}\text { - Presence of fever }\left(>37,5^{\circ} \mathrm{C}\right) \\
\text { - Presence of respiratory symptoms: cough, shortness of breath } \\
\text { - Sudden onset of anosmia, ageusia or dysgeusia } \\
\text { - Conjunctivitis } \\
\text { - Diarrhoea } \\
\text { - Fatigue } \\
\text { - Muscle or body aches } \\
\text { - Headache } \\
\text { - Sore throat } \\
\text { - Congestion or runny nose } \\
\text { - Nausea or vomiting }\end{array}$} \\
\hline Epidemiological & \multicolumn{5}{|c|}{$\begin{array}{l}\text { - Close contact with a person known or suspected to have coronavirus. The patient has been in an area where ongoing COVID- } \\
19 \text { transmission has been confirmed. The patient has ever been diagnosed with COVID-19 infection Date of diagnosis Time } \\
\text { since recovery }\end{array}$} \\
\hline
\end{tabular}

of the technique to collect the nasopharyngeal swab. RTPCR can remain positive for as long as 3 weeks from the onset of the symptoms. ${ }^{74}$ A positive RT-PCR result represents only the detection of viral RNA and does not necessarily indicate that the virus is viable. ${ }^{75}$

Diagnostic Tests for Detection of Antibodies Against SARS-CoV-2: IgM and IgG

The tests that detect antibodies against SARS-CoV-2 are not the gold standard to diagnose an active infection. They are tools that help to know, still with an important degree of uncertainty, if the patient has been in contact with the virus and may give a notion of where the patient might be situated in the natural history of the disease.

These tests could give more information regarding the cases suspected to have the infection, with repeated negative
PCR results. It was proved that this group of patients can increase the risk of nosocomial transmission. ${ }^{76}$ Negative results would not exclude SARS-CoV-2 infection. ${ }^{77}$

IgM represents the humoral immune reaction to the virus. The antibody detection is performed by the enzyme-linked immunosorbent assay (ELISA). Immunoreactivity begins around the first week of symptoms onset, it reaches a peak at week three, and it lowers at week four to five. IgG can be detected after the second week and remains positive for several months. It still needs to be clarified to what extent a positive $\mathrm{IgG}$ response confers resistance to reinfection with SARS-CoV-2 and for how long (Figure 2). ${ }^{78}$

Thoracic Imaging

Role of Thoracic Imaging in Preoperative Assessment

With RT-PCR as a gold standard, chest computed 


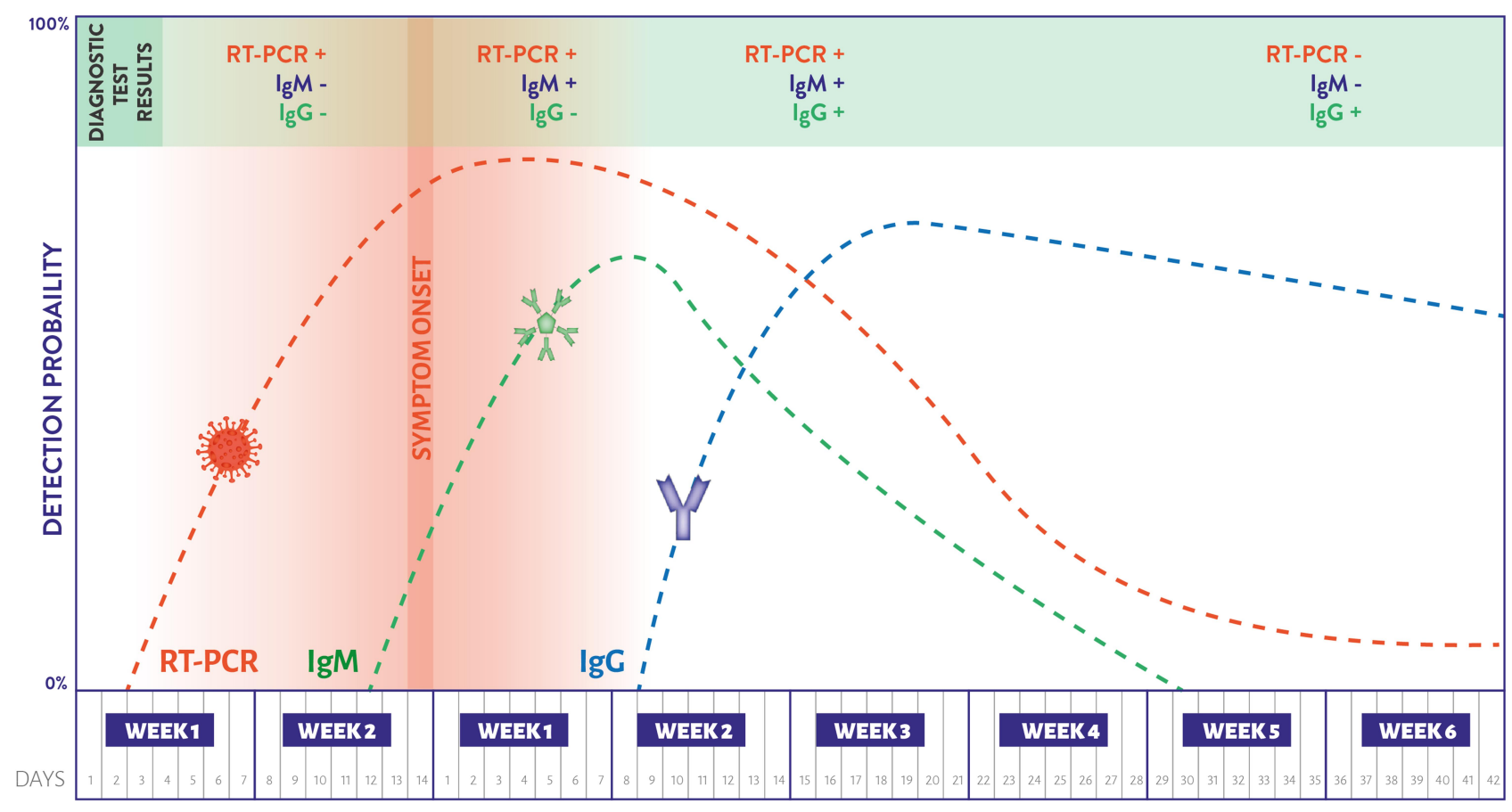

TIME COURSE

Figure 2 Chronological estimate of diagnostic test probability to detect SARS-CoV-2 in the COVID-19 natural history. Estimated time intervals should be considered approximations. Publications are not consistent with this information since many factors have a significant influence on the shift of the curves. I-PCR indicates real-time polymerase chain reaction. 2-IgM, Immunoglobulin M. 3-IgG, Immunoglobulin G.

tomography (CT) has demonstrated good-to-excellent sensitivity for detection of COVID-19 pulmonary infection in symptomatic patients (with values ranging from $56 \%$ to 97\%, reported in different series). ${ }^{60,79-81}$ However, thoracic imaging findings are nonspecific for COVID-19 infection and may be similar to those evidenced in other viral lung diseases. $^{76,79,82-87}$

Despite the sensitivity levels of chest imaging, the CDC does not currently recommend to diagnose COVID-19. This health institute states that viral testing remains the only specific method of diagnosis. Confirmation with the viral test is required even if radiologic findings are suggestive of COVID19 on radiograph or CT. Similarly, the American College of Radiology (ACR) has recently communicated CT should not be used to screen for or as a first-line test to diagnose COVID19. CT should be used sparingly and reserved for hospitalized, symptomatic patients with specific clinical indications for $\mathrm{CT}^{88}$ This statement contrasts with some guidelines that recommend chest X-rays as a preoperative exam. ${ }^{45}$

Taking into account the last considerations, among the difficulties we still encounter, the most important ones are the gaps that remain in screening asymptomatic persons during the incubation phase. ${ }^{77,89}$

\section{The New Normal: Considerations to} Perform an Elective Surgery on

\section{a Recovered COVID-I9 Patient}

In order to perform programmed eye surgery in a patient that had the infection, the advice of a specialist in COVID19 should be followed since guidelines are frequently changing. Time since diagnosis and recovery should be confirmed to uphold the decision as to whether clearance testing is required or not.

Ideally, the patient should already be asymptomatic for more than 14 days and count with two negative PCRs results separated by $24 \mathrm{~h} .{ }^{90}$ Additionally, IgM should be negative and $\mathrm{IgG}$, already with detectable titles.

\section{Operating Room Considerations SARS-CoV-2 and Eye Surgical Procedures} During eye surgery, the main factors that may impact viral transmission are 1-procedures that have the potential to generate aerosol, 2-working distance between ophthalmologist and patient, 3-prolonged time of surgery, 4-air flow, and 5-use of barrier methods and personal protective equipment (PPE). 
Ophthalmic procedures and the potential to generate aerosol in the operating room (OR):

- Phacoemulsification ${ }^{91}$

- Cautery use ${ }^{49}$

- Excimer laser ${ }^{92}$

- Vitrectomy ${ }^{93}$

- Oculoplastic, orbit, strabismus, tumoral and nasolacrimal duct surgery: Given that common ophthalmic procedures do not generate an important amount of aerosols, the main source of transmission continues to be the patient's respiratory tract. During this transition of the COVID-19 pandemic, general anaesthesia should be replaced, if the case allows it, to avoid aerosolization during intubation.

- YAG and Argon laser: They are not supposed to produce aerosol patients that need to be treated with panphotocoagulation; they are mostly diabetic and immunocompromised.

\section{Considerations for Ophthalmological Surgical Procedures to Reduce Viral Transmission}

Topical povidone-iodine use should be considered prior to any procedure to lower the risk of any unknown or uncertain evidence of virus transmission. ${ }^{93}$

Standard surgical antisepsis using povidone-iodine 5\% would reduce the viral load on the conjunctiva. Topical povidone-iodine is virucidal with in vitro testing of $0.23 \%$ povidone-iodine producing a 10,000 -fold reduction in the viral load of SARS-CoV and MERS-CoV within 15 seconds. ${ }^{94,95}$

\section{Phacoemulsification Considerations and Aerosolization During Cataract Surgery}

In the phacoemulsification procedure, the majority of the aqueous humour is visco-expressed before capsulorhexis which creates a replacement of the concerning infected intraocular fluid. Performing irrigation/aspiration for a minimum of 6 seconds prior to starting active phacoemulsification will significantly decrease the proportion of any remaining intraocular fluid (and consequently any theoretical virus load) in any aerosol produced. As a result, the aerosolization created during phacoemulsification is generated mainly from BSS (the surgery is performed in a closed intraocular system which allows this dilution process to occur). ${ }^{91}$ Administrate hydroxypropyl methylcellulose $2 \%$ (HPMC) every minute during phacoemulsification to coat the corneal surface, including the main incision. HPMC is a low viscosity and moderate viscoelastic compound, that acts as a barrier for aerosol formation and dispersion. ${ }^{96} \mathrm{~A}$ smaller incision size reduces aerosol leakage. This statement was noted in a comparison between a $2.75 \mathrm{~mm}$ tip with a $2.2 \mathrm{~mm}$ tip. ${ }^{97}$

Applying the measures mentioned above, the risk of aerosolized virus during phacoemulsification is expected to be greatly reduced.

\section{Pars Plana Vitrectomy (PPV) and Other Posterior Segment Procedures}

The PPV is expected to involve a low risk of virus transmission due to the fact that it is performed in a closed surgical system with valved trocar cannulas. Aerosol generated during any procedure is expected to be contained within the eye. However, external cautery should be minimized and performed with vigorous irrigation. ${ }^{93}$

The intravitreal injections procedure has no additional risk of transmission from the ocular surface. However, given that diabetic and elderly patients are at a higher risk for COVID-19 complications, it is important to consider prioritizing those at the greatest risk of irreversible vision loss. The Royal College of Ophthalmologists has prepared guidance as a temporary response to the clinical management of patients during the ongoing COVID-19 pandemic. ${ }^{98,99}$

\section{Cautery-Related Procedures}

Oculofacial plastics, pediatric ophthalmology, ocular surface tumours and reconstruction.

Cautery implementation should be reduced to a minimum or avoided, if possible since it has been associated with significant airborne particulate matter production. ${ }^{13}$ During cautery-related procedures, it is recommended to wear N95 masks or equivalent. ${ }^{13}$

One option to reduce cautery plume is to apply generous irrigation. Another option to consider is to perform active air suction right next to the area where coagulation is intended.

\section{Pan-Photocoagulation Treatment}

For this intervention, the physician should consider the recommendations given for eye examination. For instance, it is suggested the use of breath shield on a laser slit lamp, the hypoallergenic tape to secure the patient's surgical mask on the nasal bridge, to avoid talking, and to use proper PPE (gloves, long sleeves gowns, and respirators, if available). Instilling a drop of iodopovidone 5\% after proparacaine may be considered to reduce the possible 
presence of virus on the eye surface. Panphotocoagulation contact lenses should be disinfected according to the manufacturer's recommendations. Washing the contact lenses with detergent and water proved to be effective to control viruses and bacteria as well as disinfecting them with bleach. ${ }^{100}$

\section{General Considerations for the OR}

Each institution should adapt the recommendations according to its capabilities. It is important to critically evaluate if the institution can responsibly face the performance of the surgery of a suspected or confirmed COVID-19 patient. When it is not convenient to operate this type of patient in the institution, you should have the patient referral ready.

- Reduce personnel in the OR to the minimum needed.

- Assign an OR with different access for suspected or confirmed COVID-19 patients. $^{82}$

- Assign OR and a defined circuit for patients who have tested negative for COVID-19.

- Reduce surfaces that can be contaminated. Leave inside the OR only what will be needed during the surgery.

- Prepare an area close to the OR, as a pre OR, to leave materials that could be necessary during the surgery.

- A separate cart could be useful to the circulating nurse to move equipment or carry drugs into the OR.

- Understanding the air-flow within the OR is crucial to minimizing the risk of infection.

- OR will have negative pressure, the exchange rate of air lowers the viral shedding. ${ }^{101,102}$

- A negative pressure environment could be created in a corner of the operating complex. ${ }^{82}$

o It is recommended to use a HEPA filter.

- If OR has not the appropriate filters, air conditioning should be off.

- Maintain doors closed. Avoid opening and closing doors when not necessary. ${ }^{103}$

- The anteroom is used for donning/doffing of COVID19 PPE.

- Consider fully recovering the patient in the same $\mathrm{OR}^{82}$

\section{Workflow}

Try not to make significant changes in protocols for surgical procedures to avoid making new mistakes.

The time between patients requires proper planning to allow the new measures to be taken into consideration.

\section{Patient Preparation}

- Triage at arrival.

- Patient identification. Wristbands alert if a patient is COVID-19 suspicious.

- If the patient is COVID-19 positive/suspicious, transfer to the OR should be done with the proper preparation and coordination. Halls should be clear and be kept under surveillance by the security staff.

- Change patient

- Provide patients with a gown, shoes, a cap, and a surgical mask.

- Personal belongings can be placed in a plastic bag.

- Confirm the eye to be operated and mark it.

- Limit talking inside the OR.

\section{Staff Assignments}

Reduce the number of personnel and circulation within the operating room. It is important to plan the tasks to be carried out, the minimum necessary elements inside the $\mathrm{OR}$ and the assignment of roles. The training of all the members of the staff that work in the OR should be mandatory. It aims at avoiding cross-infection. If necessary, the staff could be trained using simulation (Table 5).

\section{OR Cleaning and Disinfection}

\section{Considerations}

Aerosol and surface stability of SARS-CoV-2 has been proven in multiple studies. The proper cleaning and disinfection in the OR are crucial for both patient and healthcare staff according to the procedures that were followed. ${ }^{14,106}$

Improve the organization in the $\mathrm{OR}$ to increase the frequency of cleaning and ensure a thorough cleaning. The time between surgeries will be compromised and should be scheduled accordingly.

These interventions require proper compliance. Evidence-based surveillance can be implemented optimizing sustainability. ${ }^{107}$

\section{Considerations for the Cleaning Personnel}

Health care workers' training, practice, and observation for infection prevention are of great importance, as well as guidance on the type of PPE, and how the donning and doffing process should be made. ${ }^{53,107-109}$

Before entering the OR, air contamination should be addressed. ${ }^{13}$ A recent study showed a 3-hour persistence of SARS-CoV-2 in aerosols. ${ }^{14}$ High-frequency air change (15-25 per hour) can rapidly reduce aerosol particles. ${ }^{102}$ 
Table 5 Staff Assignments in the Operating Room for an Ophthalmic Surgery During COVID-19 Pandemic

\begin{tabular}{|c|c|}
\hline $\begin{array}{l}\text { Member of the } \\
\text { Surgical Team }\end{array}$ & Assignments in the Operating Room \\
\hline Circulating Nurse & $\begin{array}{l}\text { - Have a preoperational checklist } \\
\text { - In charge of bringing materials and instru- } \\
\text { ments into the OR as the surgery } \\
\text { develops. }\end{array}$ \\
\hline Surgical Assistant & $\begin{array}{l}\text { - Properly plan the material that will enter } \\
\text { the OR. Any unnecessary material will be } \\
\text { assumed as contaminated and should be } \\
\text { discarded. }\end{array}$ \\
\hline Surgeon & $\begin{array}{l}\text { - The operation should be led by an experi- } \\
\text { enced surgeon to minimize complications, } \\
\text { risks, and time of exposure inside the OR. } \\
\text { - Avoid risky manoeuvres during surgery. } \\
\text { Aim to perform safe surgeries. } \\
\text { - Contemplate those surgical approaches } \\
\text { that have the lowest probability of post- } \\
\text { operative complications. }\end{array}$ \\
\hline Anesthesiologist & $\begin{array}{l}\text { Since this is one of the most exposed } \\
\text { specialities, generally anaesthetists have very } \\
\text { clear protocols to follow to reduce } \\
\text { aerosolization and extreme air } \\
\text { contamination during urgent and elective } \\
\text { surgeries. } \\
\text { - Try to avoid general anaesthesia unless } \\
\text { mandatory. } \\
\text { - Topical anaesthesia should be preferred to } \\
\text { local anaesthesia whenever possible. } \\
\text { - The OR staff must not access the OR until } \\
\text { the patient is intubated. } \\
\text { - N95 or OR PAPR (powered air-purifying } \\
\text { respirator) must be used for all aerosol- } \\
\text { generating procedures. } \\
\text { - If intubation is required for the surgery, } \\
\text { recommend intubation in a negative pres- } \\
\text { sure room prior to OR, as well as extu- } \\
\text { bation. Consider using an aerosol box to } \\
\text { reduce aerosolization in the OR. }{ }^{104,105} \\
\text { - Use an extra heat and moisture exchanger } \\
\text { (HME) filter and viral filter on the expira- } \\
\text { tory limb of the anaesthesia machine } \\
\text { circuit. }{ }^{105} \text { Clamp endotracheal tube before } \\
\text { any disconnection is planned. }\end{array}$ \\
\hline
\end{tabular}

When entering the OR after surgery of a COVID-19 positive patient, the use of PPE is mandatory (face shield or goggles, N95 or higher respirator, isolation gown, a pair of non-sterile gloves). ${ }^{53}$

\section{Disinfectant Solutions}

Disinfectant solutions proven to eliminate the virus are sodium hypochlorite $0.21 \%$ (Figure 3 ), alcohol solutions at $70-95 \%$, and hydrogen peroxide at $0.5 \%$, glutaraldehyde $0.5-2.5 \%$, formaldehyde $0.7-1 \%$ and quaternary ammonium. ${ }^{15,109-111}$ The specific disinfectant solution should be used as instructed by the manufacturer.

A simple approach consists in wet cleaning with two buckets: cleaning with detergent $(10 \mathrm{ml}$ of detergent diluted in 10 litres of warm water), then disinfecting all the surfaces with sodium hypochlorite at $0.5 \%{ }^{112}$

The cleaning sequence should remain the same. Decontaminate all surfaces, considering screens, keyboard, mouse, cables, monitors, and anaesthesia machines. For proper inactivation of the coronavirus, surfaces should be exposed to solutions for at least 1 minute. ${ }^{15}$

Some protocols consider the use of hydrogen peroxide vaporizers, UV-C lights and chlorine dioxide solution to decontaminate the OR. More evidence-based research should be done to adopt these recommendations.

\section{Considerations After Surgery, Follow-Ups, and Complications}

The same criteria used for previous processes should be applied here: reduce patient time spent at the institution and employ proper use of hygiene and barrier methods. For surgical patients, one needs to consider several factors before proceeding, such as anaesthesia, operating room workflow/staffing, and how nursing preoperative and postoperative care will be managed. For example, if the patient requires close follow-up or may be at higher risk for postoperative complications, unless urgency or emergency, this surgical patient should be deferred so as not to make them run the unnecessary risk of contracting the virus with a potentially unfavourable outcome. Virtual visits: try to make follow-ups using telemedicine.

- Reduce the face-to-face visit rate.

- Provide the patient with written instructions and alarm symptoms, as well as ways of seeking medical assistance.

- The postoperative exam is hard to be replaced. However, if required, try to streamline the examination by testing what is essential and hold the rest of the consultation by phone or using telemedicine.

Proper documentation of the steps aimed at mitigating the transmission of the virus and keeping patients and staff 


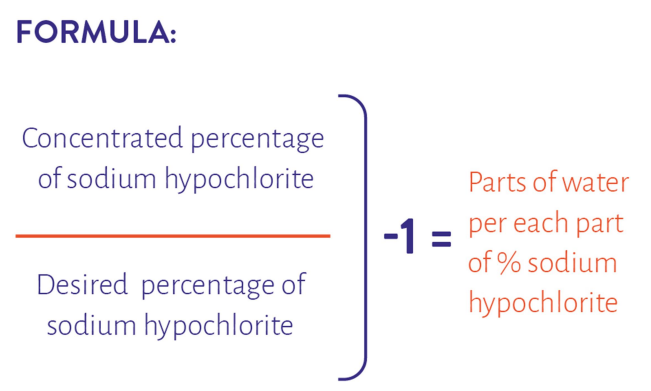

EXAMPLE:

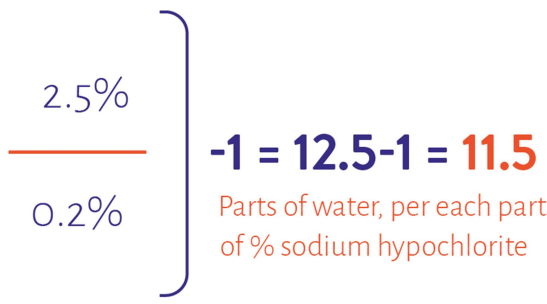

Figure 3 Formula to dilute sodium hypochlorite at desired concentration.

safe is prudent, safeguarding yourself and the institution against legal action. We encourage ophthalmologists to take special consideration not only to actively work on prevention but also to document proof of all the measures and special precautions taken. Thus, it is recommended that the medical record reflects good rationale as to why the patient was operated during this pandemic and that it includes the patient's consent to the possibility of increased morbidity. During the COVID-19 pandemic, it is important to demonstrate that the institution has implemented measures to avoid viral dissemination and has taken special care to address patients' concerns.

The lack of adequate legal protection for surgeons seems to have an impact in some institutions, reducing the volume of surgical interventions during a pandemic era and the immediately following period. This needs to shift, in order to provide efficient health care to all patients. ${ }^{34}$

\section{Discussion}

In this review, we aim to provide information as well as several recommendations for ophthalmologists and healthcare institutions to better adapt to the new situation created by the COVID-19 pandemic.

First, regarding hospital triage: a reasonable approach to help standardize indications and preserve resources for more urgent cases according to ICU occupancy has been adapted following, in part, the proposals by the Spanish Association of Surgeons. Although this model has not yet been validated, its usefulness seems reasonable. In addition, we have outlined factors for the surgeon to keep in mind when judging surgical indications.

Second, the eye as a source of viral transmission: the presence of SARS-CoV-2 on the ocular surface and its infectious capacity is an obvious major concern in the ophthalmologic community. Although this remains controversial, it should soon be clarified by evidence. After writing this review, we realize that considering the eye as a source of viral dissemination for the ophthalmologist may not have the expected relevance. The reason for this is that tears and ocular secretions are body fluids we should always be aware of and not only during the COVID-19 pandemic. Taking the precautions mentioned above, the risk of transmission can be significantly lowered while providing care of ophthalmic patients. The focus of concern should continue to be the respiratory tract as the main source of viral spread.

Third, viral screening and testing: there are multiple approaches in the screening process to rule out COVID19; up to now, they have shown to be expensive, extensive and non-conclusive. Significant work has gone into making diagnostic tests more reliable and accessible. However, beyond this, given the possibility that a COVID-19 patient may not be detected by screening, precautions and protections should never be avoided.

Fourth, viral transmission: the airborne route of transmission is still controversial, and this explains the main differences in PPE recommendations. On the one hand, the World Health Organization recommends droplet and contact precautions for those people caring for COVID-19 patients. Their argument is that airborne transmission remains unproven in clinical situations since it was not reported in the analysis of 75,465 COVID-19 cases in China. Furthermore, airborne evidence was studied in simulated conditions and was largely not peer-reviewed.

On the other hand, the US CDC and the European Centre for Disease Prevention and Control recommend airborne precautions for any situation involving the care of COVID-19 patients and consider the use of medical masks as an acceptable option in case of respirator 
shortages. Moreover, it is unanimously recommended to use full protection for aerosol-generating procedures.

Fifth, following all the recommendations to take care of the health of patients and workforce at ophthalmic institutions becomes unproductive when 24-hour personal care is not taken.

Until the COVID-19 pandemic reaches its end, it is crucial to monitor new publications and recommendations, remaining flexible in order to actively make appropriate modifications during this pandemic.

\section{Conclusion}

When facing a viral pandemic, our suggestion is that a designated group or committee summarizes preferred practices and tailors them to the particular institution. They should take into account the epidemiologic context, the local regulations, the patient's needs, the economic situation, the access to diagnostic tests, and the services offered.

Making a triage according to the patient's conditions and eye pathology, reducing the time the patient is at the institution, keeping social distancing, accurately using personal protective equipment (PPE), placing barrier methods, taking care of hygiene, as well as following other recommendations mentioned in this review, will allow physicians to take care of the visual health of the patients while reducing the impact of the COVID-19 pandemic.

\section{Disclaimer}

The authors would like to declare that this document contains recommendations based on the best evidence found at the moment of writing, and also contains personal analysis considered important for ophthalmology.

This document does not have the intention to set a standard of care and cannot ensure a successful outcome in every situation. These guidelines aim to help adapt protocols according to the regional, local and individual hospital policies and expertise. New information regarding this topic may change the recommendations in this review in a significant way; and therefore, we cannot warrant the completeness of the guidance.

\section{Acknowledgments}

To Ana Vigil for her support and technical assistance. To Carolina Inés Salica for her dedication and technical assistance in her field. To Marcelo Reyes for his contribution to the topic in his expertise in diagnostic imaging. To all members of the Committee for Prevention of Ocular Infections that help and inspire to seek a deeper understanding of this pandemic as well as ways to help mitigate its impact.

We wish to make a special mention for Dr. Li Wenliang to whom this article is dedicated, along with all the colleges and healthcare workers who departed while providing health service to their communities during the COVID-19 pandemic.

\section{Funding}

The authors declare no specific grant for this research.

\section{Disclosure}

Roberto Pineda 11 reports personal fees from SanofiGenzyme and royalties from Elsevier, outside the submitted work. The authors report no other potential conflicts of interest for this work.

\section{References}

1. World Health Organization. Report of the WHO-China Joint Mission on Coronavirus Disease 2019 (COVID-19). Available from: https://www.who.int/publications/i/item/report-of-the-whochina-joint-mission-on-coronavirus-disease-2019-(covid-19). Accessed December 22, 2020.

2. World Health Organization. Archived: WHO Timeline - COVID-19. 2020. Available from: https://www.who.int/news-room/detail/2704-2020-who-timeline - covid-19. Accessed December 22, 2020.

3. World Health Organization. WHO Statement regarding cluster of pneumonia cases in Wuhan, China. 2020. Available from: https:// www.who.int/china/news/detail/09-01-2020-who-statementregarding-cluster-of-pneumonia-cases-in-wuhan-china. Accessed December 22, 2020.

4. Reviglio VE, Osaba M, Reviglio V, Chiaradia P, Kuo IC, O'brien TP. COVID-19 and ophthalmology: a new chapter in an old story. Med Hypothesis Discov Innov Ophthalmol. 2020;9 (2):71-73. doi:10.1016/s0140-6736

5. World Health Organization. Prevention of Hospital-Acquired Infections a Practical Guide. 2nd ed. 2020. Available from: http://www.who.int/emc. Accessed December 22, 2020.

6. World Health Organization. Modes of transmission of virus causing COVID-19: implications for IPC precaution recommendations. 2020. Available from: https://www.who.int/ news-room/commentaries/detail/modes-of-transmission-of-viruscausing-covid-19-implications-for-ipc-precautionrecommendations. Accessed December 22, 2020.

7. Liu J, Liao X, Qian S, et al. Community transmission of severe acute respiratory syndrome Coronavirus 2, Shenzhen, China, 2020. Emerg Infect Dis. 2020;26(6):1320-1323. doi:10.3201/ eid2606.200239

8. Napoli PE, Nioi M, D'Aloja E, Fossarello M. The ocular surface and the coronavirus disease 2019: does a dual 'ocular route' exist?. J Clin Med. 2020;9(5):1269. doi:10.3390/jcm9051269

9. Shang J, Wan Y, Luo C, et al. Cell entry mechanisms of SARS-CoV-2. Proc Natl Acad Sci U S A. 2020;117:21. doi:10.1073/pnas.2003138117

10. Deng W, Bao L, Gao H, et al. Ocular conjunctival inoculation of SARS-CoV-2 can cause mild COVID-19 in rhesus macaques. Nat Commun. 2020;11:1. doi:10.1038/s41467-020-18149-6

11. Chen Y, Chen L, Deng Q, et al. The presence of SARS-CoV-2 RNA in the feces of COVID-19 patients. $J$ Med Virol. 2020;92 (7):833-840. doi:10.1002/jmv.25825 
12. Schwartz DA. An analysis of 38 pregnant women with COVID-19, their newborn infants, and maternal-fetal Transmission of SARS-CoV-2: maternal coronavirus infections and pregnancy outcomes. Arch Pathol Lab Med. 2020; (7):799-805. doi:10.5858/arpa.2020-0901-SA

13. Chia PY, Coleman KK, Tan YK, et al. Detection of air and surface contamination by SARS-CoV-2 in hospital rooms of infected patients. Nat Commun. 2020;11:1. doi:10.1038/s41467020-16670-2

14. Van Doremalen N, Bushmaker T, Morris DH, et al. Aerosol and surface stability of SARS-CoV-2 as compared with SARS-CoV-1. $N$ Engl J Med. 2020;382(16):1564-1567. doi:10.1056/NEJMc 2004973

15. Godri Pollitt KJ, Peccia J, Ko AI, et al. COVID-19 vulnerability: the potential impact of genetic susceptibility and airborne transmission. Hum Genomics. 2020;14:1. doi:10.1186/s40246020-00267-3

16. Wright WF. Essentials of Clinical Infectious Diseases. Springer Publishing Company; 2018; doi:10.1891/978082612 7822

17. Lingli A, Xu Z, Castiglione GM, et al. ACE2 and TMPRSS2 are expressed on the human ocular surface, suggesting susceptibility to SARS-CoV-2 infection. bioRxiv. 2020. doi:10.1101/2020.05. 09.086165

18. Xuejie L, Ming W, Jing D, Wenjun W, Yanning Y, Wei J. Novel coronavirus disease with conjunctivitis and conjunctivitis as first symptom: two cases report. CJEO J. 2020. doi:10.0376/cma.j. cn.115989-20200303-00133

19. Ying NY, Idris NS, Muhamad R, Ahmad I. Coronavirus disease 2019 presenting as conjunctivitis. Korean J Fam Med. 2020 doi: $10.4082 / \mathrm{kjfm} .20 .0090$

20. Zhang X, Chen X, Chen L, et al. The evidence of SARS-CoV-2 infection on ocular surface. Ocul Surf. 2020;18(3):360-362. doi:10.1016/j.jtos.2020.03.010

21. Kumar K, Prakash AA, Gangasagara SB, et al. Presence of viral RNA of SARS-CoV-2 in conjunctival swab specimens of COVID-19 patients. Indian $J$ Ophthalmol. 2020;68(6):10 15-1017. doi:10.4103/ijo.IJO_1287_20

22. Yu A-Y, Tu R, Shao X, Pan A, Zhou K, Huang J. A comprehensive Chinese experience against SARS-CoV-2 in ophthalmology. Eye Vis. 2020;7:1. doi:10.1186/s40662-020-00187-2

23. Napoli PE, Mangoni L, Gentile P, Braghiroli M, Fossarello MA. Panel of broad-spectrum antivirals in topical ophthalmic medications from the drug repurposing approach during and after the Coronavirus Disease 2019 Era. J Clin Med. 2020;9(8):2441. doi: $10.3390 / \mathrm{jcm} 9082441$

24. Casagrande M, Fitzek A, Püschel K, et al. Detection of SARS-CoV-2 in human retinal biopsies of deceased COVID-19 Patients. Ocul Immunol Inflamm. 2020;28(5):721-725. doi:10.10 80/09273948.2020.1770301

25.. Invernizzi A, Torre A, Parrulli S, et al.. Retinal findings in patients with COVID-19: results from the SERPICO-19 study. EClinicalMedicine. 2020:27. doi:10.1016/j.eclinm.2020. 100550 .

26.. Lauermann P, Storch M, Weig M, et al.. There is no intraocular affection on a SARS-CoV-2 - Infected ocular surface. Am J Ophthalmol Case Reports. 2020:20. doi:10.1016/j.ajoc.2020. 100884.

27. Marinho PM, Marcos AAA, Romano AC, Nascimento $H$, Belfort R. Retinal findings in patients with COVID-19. Lancet. 2020;395(10237):1610. doi:10.1016/S0140-6736(20)31 014-X

28. Cheema M, Aghazadeh H, Nazarali S, et al. Keratoconjunctivitis as the initial medical presentation of the novel coronavirus disease 2019 (COVID-19). Can J Ophthalmol. 2020;55(4):e125e129. doi:10.1016/j.jcjo.2020.03.003
29. Sarma P, Kaur H, Kaur H, et al. Ocular manifestations and tear or conjunctival Swab PCR positivity for 2019-nCoV in Patients with COVID-19: a systematic review and meta-analysis. SSRN Electron J. 2020. doi:10.2139/ssrn.3566161

30. Tu Y-P, Jennings R, Hart B, et al. Swabs collected by patients or health care workers for SARS-CoV-2 testing. $N$ Engl J Med. 2020;383(5):494-496. doi:10.1056/nejmc2016321

31. Giannaccare G, Vaccaro S, Mancini A, Scorcia V. Dry eye in the COVID-19 era: how the measures for controlling pandemic might harm ocular surface. Graefe's Arch Clin Exp Ophthalmol. 2020;258(11):2567-2568. doi:10.1007/s00417020-04808-3

32. Shetty R, Jayadev C, Chabra A, et al. Sanitizer aerosol-driven ocular surface disease (SADOSD) - a COVID-19 repercussion?. Indian $J$ Ophthalmol. 2020;68(6):981-983. doi:10.4103/ijo. IJO_1308_20

33. Toro $\mathrm{MD}$, Brézin AP, Burdon $\mathrm{M}$, et al. Early impact of COVID-19 outbreak on eye care: insights from EUROCOVCAT group. Eur J Ophthalmol. 2020. doi:10.1177/ 1120672120960339

34. Napoli PE, Nioi M, D’Aloja E, Fossarello M. Safety recommendations and medical liability in ocular surgery during the COVID-19 pandemic: an unsolved dilemma. J Clin Med. 2020;9(5):1403. doi:10.3390/jcm9051403

35. Sirna L, Muñoz Ratto H, Talmazan Y Medical workers in Spain and Italy "overloaded" as more of them catch coronavirus. Available from: https://www.nbcnews.com/news/world/medicalworkers-spain-italy-overloaded-more-them-catch-coronavirusn1170721. Accesed March 30, 2020.

36. Korobelnik JF, Loewenstein A, Aslam T, et al. Communicating with patients with nAMD and their families during the COVID-19 pandemic. Graefe's Arch Clin Exp Ophthalmol. 2020;258(6):1335-1337. doi:10.1007/s00417-020-04697-6

37. Lai THT, Tang EWH, Chau SKY, Fung KSC, Li KKW. Stepping up infection control measures in ophthalmology during the novel coronavirus outbreak: an experience from Hong Kong. Graefe's Arch Clin Exp Ophthalmol. 2020;258(5):1049-1055. doi:10.1007/ s00417-020-04641-8

38. World Health Organization. WHO Guidelines on Hand Hygiene in Health Care: A Summary First Global Patient Safety Challenge Clean Care Is Safer Care.; 2009. Available from: https://apps.who.int/iris/bitstream/handle/10665/70126/WHO I E R_P S P_ 2009.07 e n g.pd f; j s e s s i o n i d= 9C32BA9D36C2C5C46F92DC37B2226A82? sequence $=1$.

39. Borrone R. Consejo Argentino de Oftalmología. Consentimiento informado para la consulta oftalmológica presencial en el contexto de la pandemia COVID19. Consejo Argentino de Oftalmología. 2020. Available from: https://oftalmologos.org.ar/ files/herramientas/consentimientos/00.01b.pdf

40. COVID-19 personal protective equipment (PPE) - GOV.UK. Public Health England. Available from: https://www.gov.uk/gov ernment/publications/wuhan-novel-coronavirus-infectionprevention-and-control/covid-19-personal-protective-equipmentppe. Accessed June 18, 2020.

41. Romano MR, Montericcio A, Montalbano C, et al. Facing COVID-19 in Ophthalmology Department. Curr Eye Res. 2020;45(6):653-658. doi:10.1080/02713683.2020.1752737

42. Siddharta A, Pfaender S, Jane Vielle N, et al.. Virucidal activity of world health organization-recommended formulations against enveloped viruses, including Zika, Ebola, and Emerging Coronaviruses. J Infect Dis. 2017;6:902-906.

43. Chu DK, Akl EA, Duda S, et al. Physical distancing, face masks, and eye protection to prevent person-to-person transmission of SARS-CoV-2 and COVID-19: a systematic review and meta-analysis. Lancet. 2020;395:10242. doi:10.1016/S0140-67 36(20)31142-9 
44. U.S. Centers for Disease Control and Prevention. COVID-19: Strategies for Optimizing the Supply of PPE. Available from: https://www.cdc.gov/coronavirus/2019-ncov/hcp/ppe-strategy /index.html. May 18, 2020.

45. Sengupta S, Honavar SG, Sachdev MS, et al. All India ophthalmological society - Indian journal of ophthalmology consensus statement on preferred practices during the COVID-19 pandemic. Indian J Ophthalmol. 2020;68(5):711-724. doi:10.4103/ijo.IJO_871_20

46. PPE and staff protection requirements for ophthalmology. Public Health England. Available from: https://www.rcophth.ac.uk/wpcontent/uploads/2020/04/PPE-and-staff-protection-requirementsfor-ophthalmology-Principles.docx-1.pdf. Accessed April 3, 2020.

47. Bartoszko JJ, Farooqi MAM, Alhazzani W, Loeb M. Medical masks vs N95 respirators for preventing COVID-19 in healthcare workers: a systematic review and meta-analysis of randomized trials. Influenza Other Respi Viruses. 2020;14(4):365-373. doi:10.1111/irv.12745

48. N95 Respirators, Surgical Masks, and Face Masks | FDA. U.S. Food and Drug Administration. Available from:https://www.fda. gov/medical-devices/personal-protective-equipment-infectioncontrol/n95-respirators-surgical-masks-and-face-masks\#s2. 2020.

49. Workman AD, Jafari A, Welling DB, et al. Airborne aerosol generation during endonasal procedures in the era of COVID-19: risks and recommendations. Otolaryngol Head Neck Surg. 2020;163(3):465-470. doi:10.1177/0194599820931805

50. Prakash A, Rao H, Nair P, Talwar S, Kumar V, Talwar D. Sterilization of N95 respirators: the time for action is upon us!. Lung India. 2020;37(3):260-262. doi:10.4103/lungindia. lungindia_191_20

51. Widmer AF, Richner G. Proposal for a EN 149 acceptable reprocessing method for FFP2 respirators in times of severe shortage. Antimicrob Resist Infect Control. 2020;9(1):88. doi:10.1186/ s13756-020-00744-3

52. Zulauf KE, Green AB, Ba ANN, et al. Microwave-generated steam decontamination of N95 respirators utilizing universally accessible materials. MBio. 2020;11:3. doi:10.1128/MBIO.009 97-20

53. U.S. Centers for Disease Control and Prevention. Using Personal Protective Equipment (PPE). Available from: https://www.cdc. gov/coronavirus/2019-ncov/hcp/using-ppe.html. Accessed June 11, 2020.

54. Britt JM, Clifton BC, Barnebey HS, Mills RP. Microaerosol formation in noncontact 'air-puff' tonometry. Arch Ophthalmol. 1991;109(2):225-228. doi:10.1001/archopht.1991.01080020071 046

55. Gan CCR, Tseng YC, Lee KI. Acrylic window as physical barrier for Personal Protective Equipment (PPE) conservation. $\mathrm{Am}$ J Emerg Med. 2020;38:7. doi:10.1016/j.ajem.2020.04.044

56. Tsegaw A, Tsegaw A, Abula T, Assefa Y. Bacterial contamination of multi-dose eye drops at ophthalmology department, University of Gondar, Northwest Ethiopia. Middle East Afr J Ophthalmol. 2017;24(2):81-86. doi:10.4103/meajo.MEAJO_308_16

57. ZEISS International. Disinfecting Ophthalmic Devices. ZEISS Medical Technology. Available from: https://www.zeiss.com/med itec/int/med-support-now/disinfecting-ophthalmic-devices.html. Accessed December 22, 2020.

58. Public Health England. COVID-19: guidance on social distancing and for vulnerable people. GOV.UK. Available from: https:// www.gov.uk/government/publications/covid-19-guidance-onsocial-distancing-and-for-vulnerable-people. Accessed March 16, 2020.

59. World Health Organization. Coronavirus Disease (COVID-19) Situation Reports; 2020. Available from: https://www.who.int/ emergencies/diseases/novel-coronavirus-2019/situation-reports/. Accessed December 22, 2020.
60. Weinstock MB, Echenique A, Russell JW, et al., Chest X-Ray Findings in 636 ambulatory patients with COVID-19 presenting to an urgent care center: a normal chest X-Ray is no guarantee. J Urgent Care Med. 2020;May:13-18.

61. Consejo Argentino de Oftalmología. Consejo para determinar urgencias oftalmológicas en el contexto de la pandemia COVID-19. Available from: https://oftalmologos.org.ar/files/insti tucional/covid/web/20200406-V1-lista-de-patologias-urgentes. pdf. Accessed December 22, 2020.

62. American Academy of Ophthalmology. List of urgent and emergent ophthalmic procedures. 2020. Available from: https://www. aao.org/headline/list-of-urgent-emergent-ophthalmic-procedures.

63. U.S Centers for Disease Control and Prevention. People Who Are at Increased Risk for Severe Illness. 2020. Available from: https://www. cdc.gov/coronavirus/2019-ncov/need-extra-precautions/people-atincreased-risk.html?CDC_AA_refVal=https $\% 3 \mathrm{~A} \% 2 \mathrm{~F} \% 2 \mathrm{Fwww} . c d c$. gov\%2Fcoronavirus\%2F2019-ncov\%2Fneed-extra-precautions\% 2Fpeople-at-higher-risk.html. Accessed December 22, 2020.

64. Archer JE, Odeh A, Ereidge S, et al. Mortality and pulmonary complications in patients undergoing surgery with perioperative SARS-CoV-2 infection: an international cohort study. Lancet. 2020;396:10243. doi:10.1016/S0140-6736(20)31182-X

65. Prachand VN, Milner R, Angelos P, et al. Medically necessary, time-sensitive procedures: scoring system to ethically and efficiently manage resource scarcity and provider risk during the COVID-19 Pandemic. J Am Coll Surg. 2020;231(2):281-288. doi:10.1016/j.jamcollsurg.2020.04.011

66. Asociación Española de Cirujanos. Escala Dinámica de Fases de Alerta/Escenarios Durante La Pandemia COVID-19. Madrid; 2020. Available from: https://www.aecirujanos.es/files/noticias/152/docu mentos/Fases_de_alerta__v_3.pdf. Accessed December 22, 2020.

67. Peters AW, Chawla KS, Turnbull ZA. Transforming ORS into ICUs. N Engl J Med. 2020;382:19. doi:10.1056/NEJMc2010853

68. Wu X, Cai Y, Huang X, et al. Co-infection with SARS-CoV-2 and influenza a virus in patient with pneumonia, China. Emerg Infect Dis. 2020;26(6):1324-1326. doi:10.3201/EID2606.200299

69. Pan L, Mu M, Yang P, et al. Clinical characteristics of COVID-19 patients with digestive symptoms in Hubei, China: A descriptive, cross-sectional, multicenter study. Am J Gastroenterol. 2020;115 (5):766-773. doi:10.14309/ajg.0000000000000620

70. U.S. Centers for Disease Control and Prevention. Interim Clinical Guidance for Management of Patients with Confirmed Coronavirus Disease (COVID-19). Available from: https://www. cdc.gov/coronavirus/2019-ncov/hcp/clinical-guidancemanagement-patients.html. Accessed June 30, 2020.

71. Asociación Española de Cirujanos. Recomendaciones para la programación de cirugía en condiciones de seguridad durante el periodo de transición de la Pandemia COVID-19. 2020. Available from: https://www.aecirujanos.es/Recomendaciones-para-laprogramacion-de-cirugia-en-condiciones-de-seguridad-durante-el -periodo-de-transicion-de-la-Pandemia-

COVID19_es_102_525_0_0.html. Accessed December 22, 2020.

72. European Centre for Disease Prevention and Control. Contact tracing: public health management of persons, including healthcare workers, having had contact with COVID-19 cases in the European Union - second update. 2020. Available from: https:// www.ecdc.europa.eu/en/covid-19-contact-tracing-public-healthmanagement. Accessed December 22, 2020.

73. Cao G, Tang S, Yang D, et al. The potential transmission of SARS-CoV-2 from patients with negative RT-PCR swab tests to others: two related clusters of COVID-19 outbreak. Jpn J Infect Dis. 2020;73(6):399-403. doi:10.7883/yoken.jjid.2020.165

74. Zheng S, Fan J, Yu F, et al. Viral load dynamics and disease severity in patients infected with SARS-CoV-2 in Zhejiang province, China, January-March 2020: retrospective cohort study. BMJ. 2020;369:369. doi:10.1136/bmj.m1443 
75. U.S. Centers for Disease Control and Prevention. Overview of Testing for SARS-CoV-2. 2020. Available from:https:/www.cdc.gov/corona virus/2019-ncov/hcp/testing-overview.html?CDC_AA_refVal=https $\% 3 \mathrm{~A} \% 2 \mathrm{~F} \% 2 \mathrm{Fwww} . \mathrm{cdc}$.gov $\% 2 \mathrm{~F}$ coronavirus $\% 2 \mathrm{~F} 2019-$ ncov$\% 2 \mathrm{Fhcp}$ \%2Fclinical-criteria.html. Accessed December 22, 2020.

76. Cheng MP, Papenburg J, Desjardins M, et al. Diagnostic testing for severe acute respiratory syndrome-related Coronavirus 2: a narrative review. Ann Intern Med. 2020;172(11):726-734. doi:10.7326/M20-1301

77. European Centre for Disease Prevention and Control. Discharge Criteria for Confirmed COVID-19 Cases.; 2020. Available from: http:/www.ecdc.europa.eu/sites/default/files/documents/COVID19-Discharge-criteria.pdf. Accessed December 22, 2020.

78. Sethuraman N, Jeremiah SS, Ryo A. Interpreting diagnostic tests for SARS-CoV-2. J Am Med Assoc. 2020;323(22):2249-2251. doi:10.1001/jama.2020.8259

79. Li Y, Xia L. Coronavirus disease 2019 (COVID-19): role of chest CT in diagnosis and management. Am J Roentgenol. 2020;214 (6):1280-1286. doi:10.2214/AJR.20.22954

80. Ai T, Yang Z, Hou H, et al. Correlation of Chest CT and RT-PCR Testing in Coronavirus Disease 2019 (COVID-19) in China: a report of 1014 cases. Radiology. 2020;296(2):200642. doi:10.1148/radiol.2020200642

81. Caruso D, Zerunian M, Polici M, et al. Chest CT Features of COVID-19 in Rome, Italy.. Radiology. 2020;296(2):201237. doi:10.1148/radiol.2020201237

82. Ti LK, Ang LS, Foong TW, Ng BSW. What we do when a COVID-19 patient needs an operation: operating room preparation and guidance. Can J Anesth. 2020;67(6):756-758. doi:10.1007/s12630-020-01617-4

83. Bernheim A, Mei X, Huang M, et al. Chest CT findings in coronavirus disease 2019 (COVID-19): relationship to duration of infection. Radiology. 2020;295(3):685-691. doi:10.1148/radiol.2020200463

84. Huang C, Wang Y, Li X, et al. Clinical features of patients infected with 2019 novel coronavirus in Wuhan, China. Lancet 2020;395(10223):497-506. doi:10.1016/S0140-6736(20)30183-5

85. Chung M, Bernheim A, Mei X, et al. CT imaging features of 2019 novel coronavirus (2019-NCoV). Radiology. 2020;295(1):20 2-207. doi:10.1148/radiol.2020200230

86. Pan F, Ye T, Sun P, et al. Time course of lung changes at chest CT during recovery from Coronavirus disease 2019 (COVID-19). Radiology. 2020;295(3):715-721. doi:10.1148/radiol.2020200370

87. Wong HYF, Lam HYS, Fong AHT, et al.. Frequency and distribution of chest radiographic findings in COVID-19 positive patients. Radiology. 2019:201160. doi:10.1148/radiol.2020201160.

88. American College of Radiology. ACR Recommendations for the use of Chest Radiography and Computed Tomography (CT) for Suspected COVID-19 Infection. Available from: https://www.acr. org/Advocacy-and-Economics/ACR-Position-Statements /Recommendations-for-Chest-Radiography-and-CT-for-Suspected -COVID19-Infection. Accessed March 22, 2020.

89. Khunti K, Trish G, Chan XH, et al. What is the efficacy of eye protection equipment compared to no eye protection equipment in preventing transmission of COVID-19-type respiratory illnesses in primary and community care? The Centre for Evidence-Based Medicine develops, promotes and disseminates better evidence for healthcare. Available from: https://www.cebm.net/covid-19/ what-is-the-efficacy-of-eye-protection-equipment-compared-tono-eye-protection-equipment-in-preventing-transmission-of-covid -19-type-respiratory-illnesses-in-primary-and-community-care/. Accessed, 2020.

90. U.S. Centers for Disease Control and Prevention. Discontinuation of Transmission-Based Precautions and Disposition of Patients with COVID-19 in Healthcare Settings (Interim Guidance). Available from:https://www.cdc.gov/coronavirus/2019-ncov/hcp/ disposition-hospitalized-patients.html. Accessed May 2, 2020.
91. Darcy K, Elhaddad O, Achiron A, et al. Reducing visible aerosol generation during phacoemulsification in the era of Covid-19. Eye. 2020. doi:10.1038/s41433-020-1053-3

92. Taravella MJ, Viega J, Luiszer F, et al. Respirable particles in the excimer laser plume. J Cataract Refract Surg. 2001;27 (4):604-607. doi:10.1016/S0886-3350(00)00813-0

93. Special considerations for ophthalmic surgery during the COVID-19 pandemic. American Academy of Ophthalmology. 2020. Available from: https://www.aao.org/headline/special-considerationsophthalmic-surgery-during-c Accessed December 22, 2020.

94. Wu YC, Chen CS, Chan YJ. The outbreak of COVID-19: an overview. J Chinese Med Assoc. 2020;83(3):217-220. doi:10.10 97/JCMA.0000000000000270

95. Eggers M, Koburger-Janssen T, Eickmann M, Zorn J. In vitro bactericidal and virucidal efficacy of povidone-iodine gargle/ mouthwash against respiratory and oral tract pathogens. Infect Dis Ther. 2018;7(2):249-259. doi:10.1007/s40121-018-0200-7

96. Liesegang TJ, Bourne WM, Ilstrup DM. The use of hydroxypropyl methylcellulose in extracapsular cataract extraction with intraocular lens implantation. Am J Ophthalmol. 1986;102 (6):723-726. doi:10.1016/0002-9394(86)90399-5

97. Berdahl JP, DeStafeno JJ, Kim T. Corneal wound architecture and integrity after phacoemulsification. Evaluation of coaxial, microincision coaxial, and microincision bimanual techniques. J Cataract Refract Surg. 2007;33(3):510-515. doi:10.1016/j. jcrs.2006.11.012

98. Korobelnik JF, Loewenstein A, Eldem B, et al. Guidance for anti-VEGF intravitreal injections during the COVID-19 pandemic. Graefe's Arch Clin Exp Ophthalmol. 2020;258 (6):1149-1156. doi:10.1007/s00417-020-04703-x

99. The Royal College of Ophthalmologists. Medical Retinal Management Plans during COVID-19. 2020. Available from: https://www.rcophth.ac.uk/wp-content/uploads/2020/03/MedicalRetinal-Management-Plan-during-COVID-19-UPDATED -300320-1-3.pdf. Accessed December 22, 2020.

100. Abbey AM, Gregori NZ, Surapaneni K, Miller D. Efficacy of detergent and water versus bleach for disinfection of direct contact ophthalmic lenses. Cornea. 2014;33(6):610-613. doi:10.10 97/ICO.0000000000000117

101. Wexner SD, Cortés-Guiral D, Gilshtein H, Kent I, Reymond MA. COVID-19: impact on colorectal surgery. Color Dis. 2020;22 (6):635-640. doi:10.1111/codi.15112

102. Wong J, Goh QY, Tan Z, et al. Preparing for a COVID-19 pandemic: a review of operating room outbreak response measures in a large tertiary hospital in Singapore. Can J Anesth. 2020;67(6):732-745. doi:10.1007/s12630-020-01620-9

103. Balibrea JM, Badia JM, Rubio Pérez I, et al. Surgical management of patients with COVID-19 infection. recommendations of the Spanish Association of Surgeons. Cir Esp. 2020;98 (5):251-259. doi:10.1016/j.ciresp.2020.03.001

104. Malik JS, Jenner C, Ward PA. Maximising application of the aerosol box in protecting healthcare workers during the COVID-19 pandemic. Anaesthesia. 2020;75(7):974-975. doi:10. 1111/anae. 15109

105. Tseng JY, Lai HY. Protecting against COVID-19 aerosol infection during intubation. J Chin Med Assoc. 2020;83(6):582. doi:10. 1097/JCMA.0000000000000324

106. Fathizadeh H, Maroufi P, Momen-Heravi M, et al.. Protection and disinfection policies against SARS-CoV-2 (COVID-19). Le Infez Med. 2020;28(2):185-191. https://pubmed.ncbi.nlm.nih.gov/ 32275260/.

107. Dexter F, Parra MC, Brown JR, Loftus RW. Perioperative COVID-19 defense: an evidence-based approach for optimization of infection control and operating room management. Anesth Analg. 2020;131(1):37-42. doi:10.1213/ANE.0000000000004829 
108. World Health Organization. Priority eye diseases. 2018. Available from: http://www.who.int/blindness/causes/priority/en/index7. html. Accessed December 22, 2020.

109. World Health Organization. Cleaning and disinfection of environmental surfaces in the context of COVID-19. Available from: https://www.who.int/publications/i/item/cleaning-and-disinfection -of-environmental-surfaces-inthe-context-of-covid-19. Accessed May 16, 2020.

110. Rabenau HF, Kampf G, Cinatl J, Doerr HW. Efficacy of various disinfectants against SARS coronavirus. $J$ Hosp Infect. 2005;61 (2):107-111. doi:10.1016/j.jhin.2004.12.023
111. Pereira SSP, de Oliveira HM, Turrini RNT, Lacerda RA. Disinfection with sodium hypochlorite in hospital environmental surfaces in the reduction of contamination and infection prevention: a systematic review. Rev Da Esc Enferm. 2015;49 (4):675-681. doi:10.1590/S0080-623420150000400020

112. Asociación de Anestesia Analgesia y Reanimación de Buenos Aires. Limpieza y desinfección de la sala quirúrgica. https:// www.aaarba.org/Descarga/COVID19_limpieza_sala_quirúrgica. pdf/179. 2020.

\section{Publish your work in this journal}

Clinical Ophthalmology is an international, peer-reviewed journal covering all subspecialties within ophthalmology. Key topics include: Optometry; Visual science; Pharmacology and drug therapy in eye diseases; Basic Sciences; Primary and Secondary eye care; Patient Safety and Quality of Care Improvements. This journal is indexed on PubMed

Submit your manuscript here: https://www.dovepress.com/clinical-ophthalmology-journal
Central and CAS, and is the official journal of The Society of Clinical Ophthalmology (SCO). The manuscript management system is completely online and includes a very quick and fair peer-review system, which is all easy to use. Visit http://www.dovepress.com/ testimonials.php to read real quotes from published authors. 